\title{
Los «invisibles» del comercio del libro: perfil de varios vendedores ambulantes de impresos en el XVIII
}

\author{
Alberto GAMARRA GONZALO
}

\section{Resumen}

El comercio ambulante de impresos en época moderna suscita para el caso español muchos interrogantes. Como aproximación a sus protagonistas hemos estudiado varios casos concretos, localizados en la segunda mitad del Setecientos y en distintos lugares de la Corona de Castilla, a partir de una variada documentación.

Palabras clave: Comercio de libros; Buhonero; Literatura de cordel; Siglo XVIII.

\section{The «invisible men» of the book trade: \\ a portrait of several pedlars of printed books in the eighteenth century}

Abstract

The itinerant book trade in Spain during the Early Modern period raises many questions. In an attempt to gain some familiarity with its protagonists several concrete cases from the second half of the eighteenth century and from different places in the Crown of Castile are studied.

Keywords: Book Trade; Pedlar; Chapbooks; Popular literature; Eighteenth century. 
La comercialización del libro en los siglos modernos ha sido tradicionalmente un tema menor en la historiografía española aunque en las últimas décadas ha suscitado, y sigue haciéndolo, una importante atención entre los especialistas. Empero la propia casuística de las fuentes primarias ha desviado el grueso de estos estudios hacia tres aspectos específicos: el comercio del libro internacional con España, el desarrollado con Indias desde las plazas de Sevilla y Cádiz así como numerosos análisis de los fondos de tal o cual establecimiento de librería, por lo general, a través de inventarios notariales, la trayectoria de sus propietarios, y, más recientemente, desde los catálogos de venta. Frente a ellos llama la atención el escaso interés en cuanto a la comercialización ambulante de impresos y más cuando esta modalidad supuso un indispensable canal de distribución de las existencias de impresores y otros agentes editoriales. ${ }^{1}$

\footnotetext{
1 Ya en 1958 Henri-Jean MARTiN y Lucien FEvBre daban carta de naturaleza a esta modalidad comercial al integrarla en igualdad de condiciones con la venta de libros efectuada mediante las librerías, ferias, catálogos y subastas de bibliotecas. Igualmente dejaron perfilados sus principales rasgos: su origen en Francia y Alemania desde finales del siglo XV y su pervivencia hasta el XIX; su desarrollo en espacios que desincentivaban el negocio de un librero sedentario y carentes de reglamentación, o sea, en «las ciudades pequeñas, en los pueblos y también en los campos»; el protagonismo de un determinado tipo de literatura («libritos sencillos, almanaques, pronósticos y otros calendarios para pastores o bien abecedarios») así como su maridaje con grabados religiosos y artículos de mercería; su mercado preferente («una clientela por lo común poco instruida»); su vinculación con la distribución de obras prohibidas; así como los orígenes de estos vendedores (artesanos empobrecidos, mujeres, niños). La aparición del libro. México, UTEHA, 1962, pp. 255-257. En la actualidad la importancia de este canal de venta no se discute; al respecto Jeroen SALMAN ha sentenciado que «itinerant salesman, also called pedlars, street vendors, hucksters and ballad singer, are considered to be the most important distributors of popular printed matter in Europe». «Watching the Pedlar's Movements: itinerant distribution in the urban Netherlands» en Robin MYERS \& Michael HARris (Eds.), Fairs, Markets and the Itinerant Book Trade, New Castle, Oak Knoll, 2007, p. 137. Otra monografía de este último autor, cita ineludible [Pedlars and the popular press: Itinerant Distribution Networks in England and the Netherlands (1650-1850), Leiden, Brill, 2014], facilita una completa visión sobre este fenómeno económico en otras áreas europeas al tiempo que sugiere nuevas vías de aproximación metodológica.
} 
A pesar de que Jaime Moll, ya desde mediados de los años ochenta, había reclamado estudios sobre los intermediarios de este comercio, ${ }^{2}$ sus palabras han tenido un éxito limitado. Sobre el papel, el rol de los vendedores ambulantes de impresos en época moderna se ha abordado como subordinado al estudio, principalmente filológico, y últimamente material, de su producto estrella, los pliegos de cordel, ${ }^{3}$ casi siempre ignorando las posibilidades del trabajo en archivos (con algún interesante verso suelto), ${ }^{4} \mathrm{y}$, por lo general, constriñendo en el imaginario investigador la heterogénea realidad de estos personajes a la condición, cuasi folclórica, del ciego. ${ }^{5}$ Para el XVIII, época en la que la venta ambulante de impresos parece haber alcanzado un especial desarrollo a nivel europeo, contamos únicamente con tres monografías que se interesen por el caso peninsular y que constituyen una excepción a las limitaciones referidas líneas atrás. Dos se deben a hispanistas franceses, JeanFrançois Botrel y François Lopez.

El primero, a partir de una serie de artículos aparecidos en la década de los setenta, ${ }^{6}$ profundizó en el papel jugado por los invidentes madrileños en la venta ambulante de impresos a través de su agrupación en una hermandad religiosa. Aunque el minucioso estudio de Botrel se centra sobre todo en la evolución de esta asociación, que pervivió entrado el XIX, así como los conflictos legales de sus miembros con otros participantes del mundo editorial en defensa su monopolio para la venta de cierta clase de impresos, también intenta - y lo logra - reconstruir el proceso de producción y comercialización de un pliego de cordel. El segundo, con un análisis del comercio del libro español a mediados del XVIII desde informes gubernamentales, destacó la importancia de los canales de distribución ambulantes y no especializados, tanto en el entorno rural como urbano, al tiempo que formulaba una primera clasificación de sus protagonistas. ${ }^{7}$

\footnotetext{
2 «Los surtidos de romances, coplas, historias y otros papeles» en De la imprenta al lector. Estudios sobre el libro español de los siglos XVI al XVIII, Madrid, Arco Libros, 1992, pp. 50-51.

${ }^{3}$ Por ejemplo, sin ánimo de crítica, María Cruz GarCía De EnTERría, Sociedad y poesía de cordel en el Barroco, Madrid, Taurus, 1973, en especial, pp. 76-83; María GARCía COLLADO, «Del pliego al libro. Literatura popular impresa en el Siglo de las Luces», Pliegos de bibliofilia, 4 (1998), pp. 53-67 o Laura PUERTO, «El universo del pliego poético postincunable (del despegue de la literatura popular impresa en castellano)», eHumanista, 21 (2012), pp. 257 303.

${ }^{4}$ Recordar a Pedro M. CÁTEDRA, Invención, difusión y recepción de la literatura popular impresa (siglo XVI), Badajoz, Editora Regional de Extremadura, 2002.

${ }^{5}$ Una buena revisión bibliográfica, aunque con alguna valoración matizable en lo tocante al protagonismo de los ciegos frente a otros vendedores, en Abel IGLESIAS, «El ciego callejero en la España Moderna: balance y propuestas», LaborHistórico, 2 (2016), pp. 74-90.

6 Tiempo después constituyeron el primer capítulo de Libros, Prensa y Lectura en la España del siglo XIX, Madrid, Fundación Germán Sánchez Ruipérez, 1993, pp. 15-175.

7 «Gentes y oficios de la librería española a mediados del siglo XVIII», Nueva Revista de Filología Hispánica, 33/1 (1984), pp. 165-185.
}

Titivillus, ISSN 2387-0915, ISSN-e 2603-9966, 3 (2017), pp. 91-115 
El tercer estudio, hijo de una tesis doctoral defendida en años recientes, se debe a Juan Gomis. ${ }^{8}$ Se trata de una investigación ejemplar en la que se realiza una triple aproximación al mundo de la edición popular valenciana en el XVIII: desde el estudio del tipo de literatura editada; desde el análisis documental —a través de pleitos y escrituras notariales- de los negocios de los impresores editores (más el monopolio comercial ejercido por una hermandad local de ciegos); así como una revisión del perfil del lector de estas obras.

Si bien los trabajos de Botrel y Gomis han aportado un conocimiento bastante extenso de la venta ambulante de impresos así como de las mercancías que lo componían, es de lamentar que su ámbito de estudio se haya limitado (salvo unas pocas referencias) al mercado de dos grandes ciudades y que el perfil de vendedor haya quedado absorbido por el protagonismo de los ciegos en el medio urbano (explicable por el monopolio del que gozaron y porque sus estructuras organizativas han dejado un mayor rastro documental). Está por ver si se puede extrapolar la mayoría de las conclusiones ofrecidas por Botrel y Gomis al mercadeo itinerante de impresos producido en las pequeñas y medianas ciudades —incluso algunas grandesy, sobre todo, en el ámbito rural, debido a la inexistencia de agentes monopolísticos (como las cofradías de ciegos) y a la multiplicidad de centros de edición existentes para este tipo de producto editorial. En la práctica, aunque se trata de figuras bien presentes desde las últimas décadas del siglo XVI o incluso antes, ${ }^{9}$ es mucho lo que todavía no sabemos acerca de los agentes que intervinieron, el tipo de mercancías y sus precios, circuitos y puntos de compraventa, su evolución general, etcétera.

Con objeto de responder a algunos de estos interrogantes vamos a profundizar en los perfiles de varios vendedores ambulantes de impresos, los verdaderos protagonistas invisibles del comercio del libro. Las principales fuentes consultadas, si bien unidas por desarrollarse en la segunda mitad del dieciocho, presentan una tipología variada —un pleito para dilucidar la responsabilidad sobre un impreso falsificado, un procedimiento administrativo para justificar la leva de un vagabundo y una alegación al Tribunal Supremo de la Inquisición - así como un extenso ámbito geográfico (Logroño, MadridToledo y Sevilla-Huelva).

\footnotetext{
8 Menudencias de imprenta. Producción y circulación de la literatura popular (Valencia, siglo XVIII), Valencia, Institució Alfons el Magnànim, 2015.

9 La proliferación de estos intermediarios comerciales a principios del XVII llevó a un humanista, Pedro de Valencia, a considerarlos, en compañía de prostitutas, actores y bufones, un lastre para el desarrollo económico: «Tambien son dañosos los buhoneros y los que andan á vender coplas y estampas y pronósticos y todos los tratantes de esta suerte, que con poco caudal al hombro ó en una bestia andan por todo el reino á robar y saltear, ó á mendigar con aquella cubierta». Citado en Manuel ColmeIro, Historia de la Economía Política en España, Madrid, Imprenta de D. Cipriano López, 1863, II, p. 228. La referencia me fue facilitada amablemente por el profesor Fermín de los Reyes.
} 


\section{Logroño, 1761}

Las indagaciones para localizar al impresor responsable de una edición contrahecha de pronósticos nos proporcionan los primeros perfiles de estos vendedores..$^{10} \mathrm{La}$ acción se sitúa a finales de 1761 cuando Antonio Sanz, un poderoso impresor madrileño - bien relacionado con las autoridades y al frente de un taller con una elevada carga de trabajo-,${ }^{11}$ tuvo conocimiento de la comercialización en tierras riojanas de la edición contrahecha de un almanaque -compuesto cada año por el médico y matemático cordobés Gonzalo Antonio Serrano- para el que poseía privilegio en las coronas de Castilla y Aragón. Como recuerda Moll los orígenes de este rentable monopolio editorial, de impresión anual, se localizan a mediados del siglo anterior, cuando se instituyó como una prebenda del portero del Consejo de Castilla, el cual lo cedía por un periodo de diez años a impresores o libreros a cambio de una cantidad en metálico. ${ }^{12}$ En lo tocante a la participación de Sanz parece haberse iniciado - según varias escrituras copiadas en el pleito- en 1744 cuando Tomás Escaladillo, el entonces portero, le cede por diez años el privilegio al que había accedido en 1738 y que el propio impresor volvería a renovar en 1754, ya de mano del nuevo titular de este cargo, Ortiz de Salazar, por otra década.

La impresión y venta de esta pequeña obra en exclusiva para buena parte de España era un negocio muy apetecible dada su altísima demanda, asegurada no solo por el monopolio sino también por su generalizado consumo, así como la simplicidad de su composición (año tras año se repite la misma estructura con la única actualización de sus datos) y rápida edición (un pliego de papel en octavo pobremente ilustrado con pequeñitos tacos de madera). No obstante, estas características (presentes también en títulos privilegiados como las cartillas vallisoletanas $)^{13}$ podían también llegar a perjudicar este negocio pues muchos talleres de provincias poseían la suficiente capacidad técnica para falsificar la edición legitima (facilitada además por su lejanía respecto a Madrid), la cual, además, competiría con ventaja frente a la original

\footnotetext{
10 Archivo Histórico Nacional (AHN). Consejos, 5528, exp. 10. De ahora en adelante nos remitiremos a este documento para evitar múltiples citas. Igualmente advertir que en las transcripciones incluidas en este trabajo hemos optado por respetar fielmente la versión original, sin realizar ningún cambio de estilo, ortográficos o gramaticales.

${ }^{11} \mathrm{Su}$ trayectoria puede seguirse en François LOPEZ, «Antonio Sanz, Imprimeur du Roi et l'édition populaire sous l'Ancien Régime», Bulletin Hispanique, 95/1 (1993), pp. 349-378 y Mercedes AgulLó, La imprenta y el comercio de libros en Madrid (siglos XVI-XVIII), tesis doctoral inédita, Universidad Complutense de Madrid, 1991, Diccionario, p. 302.

12 Jaime MOLL, «El privilegio del calendario anual en el siglo XVII» en Henry Ettinghausen et al., Las Relaciones de sucesos. España (1500-1750). Actas del primer Coloquio Internacional, Alcalá de Henares, Universidad de Alcalá, 1996, pp. 253-259.

13 Véase Luis Resines, La catedral de papel. Historia de las Cartillas de Valladolid, Valladolid, Diputación, 2007, en especial, pp. 109-118.
} 
al controlar los circuitos de venta regional y ofrecer un mayor margen de beneficio a los intermediarios. El privilegio del que gozaba Sanz no fue ajeno a estos problemas y así, en 1744, el propio impresor denunciaba ante el Consejo que «experimentaba notables perjuicios en la transgresión que ejecutaban los impresores de los Reinos de Navarra, Aragón, Principado de Cataluña, y señorio de Vizcaya». La competencia de la ediciones falsificadas en estos territorios no solo afectaba las ventas regionales de la legítima sino que también se introducían en la Corona de Castilla en los meses de mayor venta. Sanz, no obstante, contraatacó al lograr que el Consejo comunicará su privilegio a las autoridades locales y que se amenazara con severas penas a quien lo infringiera. No fue suficiente a tenor de lo ocurrido en Logroño.

Las cartas de dos vendedores de la cartilla legítima (Juan Carol, librero avecindado en Calahorra, y Santiago Domingo de Rivas, comerciante de Haro) levantaron las sospechas de Antonio Sanz sobre la vulneración de su privilegio en tierras riojanas. El primero, el 20 de octubre de 1761, advertía de la venta en Haro, donde solía acudir a ejercer su profesión, de pronósticos falsos, particularmente por un tendero, Gregorio Fernández. El segundo, pocos días después, denunciaba no poder dar salida a su mercancía - 2 resmas de pronósticos legítimos para el año de 1762- debido a la oferta en su localidad de falsificaciones más baratas «porque la desverguenza lo que hacen [...] que los dan a 35 reales y a 32 la resma». Este último, además de señalar igualmente a Gregorio Fernández como uno de sus competidores, recordaba que, un año atrás, un vecino de Logroño, del que no ofrece el nombre, había vendido a sus empleados 4 resmas de una edición falsificada de estos almanaques. Este último dato, en especial, permitió a Sanz apostar por el verdadero promotor de la edición contrahecha, un oscuro tipógrafo llamado Matías Moreno.

Moreno, cuya trayectoria pasada es bastante desconocida hasta su llegada a Logroño en el cambio de la década de los cincuenta con los sesenta (nacido hacia 1719, según datos dispersos, había residido en Soria, donde abrió o entró en posesión de una imprenta, cuya gestión dejaba en manos de un empleado a la par que se dedicaba a la ganadería trashumante), había acumulado en poco tiempo graves antecedentes en la impresión de ediciones ilegales. Pocos meses antes había sido condenado por la justicia de Soria a pagar 100.000 maravedís más las costas procesales por falsificar en su taller, primero, una edición del almanaque de Sanz para 1761; segundo, la cartilla de la doctrina cristiana, cuyo privilegio gozaba la catedral de Valladolid. De forma paralela el nombre de Moreno aparece por estas fechas vinculado a la falsificación de otro título privilegiado. Según denunciaba la parte perjudicada, el Hospital General de Madrid, aunque no se había logrado una condena en firme al no poderse presentar ningún ejemplar como prueba, se sospechaba que:

«por un Fulano Moreno Ympresor que parecia ser en la Ciudad de Logroño a reimprimir y vender el referido Libro y Arte de Antonio de Nebrija con el Fraude y suplantación de suponerle Ympreso en anteriores

Titivillus, ISSN 2387-0915, ISSN-e 2603-9966, 3 (2017), pp. 91-115 
años y haber falsificado la Divisa ò seña de Leon que usaba la Ympresion de dhos Hospitales en su fachada esparciendo con mucha abundancia los ejemplares de esta fraudulenta ympresion $\mathrm{p}[\mathrm{o}] \mathrm{r}$ todos los Pueblos de aquella Comarca teniendose ygual noticia al mismo tiempo de que en la Villa de Vilbao se había ejecutado sustancialmente lo mismo p[o]r un Ympresor, llamado Pedro Gayangos, residente en ella y de cuias dos prohibidas Ympresiones habian salido y bendidose tantos ejemplares en la Ciudad de Burgos, la de Vitoria y otras p[ar].tes que en todas ellas era mui corta o ninguna la Venta que habian tenido y tenian los Ympresos en uso de sus Pribilegios». ${ }^{14}$

La presencia de un buen número de pronósticos contrahechos en un área que contaba con un decidido actor en negocios semejantes fue suficiente para que Sanz se decidiese por la vía judicial. Así, el 26 de noviembre, el barón de Letosa, corregidor de Logroño, daba curso a la demanda presentada por el procurador Juan Francisco Monforte, apoderado de Sanz, y ordenaba la inspección de la imprenta y la residencia de Moreno en busca de pronósticos para pasar luego, con similar propósito, a las tres librerías y veintiséis comercios generalistas activos en la capital riojana. La búsqueda de pruebas por las autoridades, totalmente infructuosa (solo se recogieron siete almanaques legítimos en una tienda), desvió los esfuerzos de Monforte.

A requerimiento del procurador las autoridades pasaron a interrogar a Moreno, preso ya en la cárcel local por haber impreso un «papel injurioso» sin licencias, y que negó terminantemente haber participado o haber tenido noticia de la edición contrahecha; igualmente se intentó ampliar la información llamando a declarar tanto al comerciante de Haro, quien únicamente admitió haber escrito a Sanz, como al librero, el cual no pudo ser localizado. Mayor información ofreció el, hasta entonces, único intermediario conocido entre el productor y el cliente, el tendero Gregorio Fernández. Localizado a finales de noviembre en su domicilio, recién llegado de vender sus mercancías por los pueblos, quedo implicado al ofrecer un pronóstico al alguacil de Haro y reconocer que era falso. La inspección de «un saco donde tenia la tienda encerrada» — reveladora descripción de su modesto comercio itinerante- sacó a la luz veintitrés pronósticos falsos. El interrogatorio consecuente (por el que sabemos que sumaba 54 años y que no sabía firmar) no tiene desperdicio:

«Dixo que haze como mes y medio poco mas o menos que transitando el declarante con su tienda desde esta villa a la de Cuzcurrita de Rio tiron se encontro un Hombre que no conoze ni save como se llama ni tampoco donde tiene su vecindad en el camino que media desde la villa de Casa de la Reyna a la dha de Cuzcurrita el qual transitaba con un Macho y

\footnotetext{
${ }^{14}$ Copia de una «Real Provision librada en 13 de Marzo de 1761 a instancia de los Reales Ospitales de la Villa y Corte de Madriz, pa que se recojan varios ejemplares de la gramatica latina [...]». ARChIVO DE LA DiPUTACIÓN FORAL DE ÁlAVA. DH-256-6, ff. 2v-3r.
} 
le propuso si le queria comprar unas Cintas y una porzion de pronosticos de Madrid y en la yntelixenzia cierta de que serian tales el que declara habiendo sacado dho Hombre un legajo de pronosticos le tomo media resma y por ella le dio treinta $\operatorname{rr}[$ eale].s v[ello].n en que se ajusto, con que se despidio del referido Hombre y le manifesto Caminar a la Ciu.d[ad] de Vitoria a lograr el despacho de los pronosticos que llebaba con dhas Cintas; y los que tomo el que declara a excepz[i].on de los veinte y tres que existian en su poder y se le han recoxido los a vendido en esta villa y fuera de ella adonde concurre a vender».

La declaración de este «quinquillero», un sinónimo de buhonero para el Diccionario de la lengua española (en su edición de 1783), nos ofrece el primer perfil de un vendedor de impresos menores junto con quincalla (objetos de metal de poco valor como dedales, bisutería o tijeras) y que compaginaba su vecindad y comercio en Haro con la venta ambulante durante unos días, portando un saco y posiblemente a pie, por las localidades más cercanas (Cuzcurrita de Río Tirón, la localidad citada más lejana, dista unos doce kilómetros al oeste de su residencia). Como vemos, su dedicación a la reventa de este tipo de mercancía nacía de una oportunidad en el camino si bien parecía conocer bien sus posibilidades como bien de consumo, señal de haber traficado antes con estas mercancías, al aceptar un precio aceptable por media resma y haber dado salida a la mayor parte de estos almanaques en poco tiempo (de los 250 que componían la media resma comprada a la veintena que quedaba en su poder mes y medio después). De interés resulta ver como el almanaque aparecía ofertado, por el misterioso proveedor, junto con un popular producto textil (por su baratura y versatilidad), unas cintas o, en la definición de la época, el «texido largo y angosto de seda, hilo, ó lana de qualquier color, que sirve para atar, adornar ó reforzar algun vestido». Su venta común junto al hecho de que este primer intermediario cifrara el grueso de su inversión en estos dos mercancías sugiere, por una parte, su amplia demanda, y, por otra, que los dos podían tener un cliente común.

Hay que considerar finalmente el rol jugado por el primer y anónimo intermediario. Nos encontramos ante un segundo y desdibujado perfil de vendedor ambulante. Frente a Fernández este buhonero muestra algunas diferencias: la primera, que debió conocer al responsable directo de la edición fraudulenta al transportar una elevada cantidad de sus almanaques y venderlos, tanto al detalle como al por mayor; segundo, que poseía una elevada capacidad de movilidad gracias a su caballería — una mula_ y a que su ámbito de acción superaba el ámbito regional (manifiesta su intención de acabar la venta en Vitoria, a 40 kilómetros de su última posición conocida); tercero, el encuentro casual en un camino secundario entre dos vendedores ambulantes es un advertencia a la hora de minusvalorar el número e impacto económico de estos agentes (no olvidar que en Haro otros personajes, sin identificar, también habían vendido pronósticos al por mayor). Llama la atención, asimismo, los variados canales de distribución para este impreso y que no

Titivillus, ISSN 2387-0915, ISSN-e 2603-9966, 3 (2017), pp. 91-115 
quedaban reducidos al librero profesional así como el número de intercambios que mediaban entre su impresión y su lectura.

Parece como si las ediciones falsificadas de este título tuviesen, por su precio e intermediarios involucrados (con fuerte presencia en el ámbito rural), mayor capacidad de venta que las legítimas; las cuales, aún con la ventaja de salir algo antes al mercado, tenían que depender de una distribución centralizada desde Madrid y jerárquica (tanto el comerciante de Haro como el librero de Calahorra no habían comprado los pronósticos legítimos directamente sino por mediación de un librero de Burgos, José Álvarez). Tener presente además, por lo que toca a las legítimas, que las cantidades distribuidas, debido a su pequeñez (dos resmas por ejemplo), sugieren tener como destino preferente la venta detallista en el ámbito urbano.

De forma paralela continuaba las pesquisas en Logroño para recabar más pruebas contra Moreno. Estas indagaciones tomaron un rumbo imprevisto el 2 de diciembre de aquel año cuando el apoderado de Sanz, advertido de la venta en Logroño de pronósticos falsos de mano de un forastero recién llegado, acudió rápidamente al corregidor para que procediera a su detención. Con ello Monforte esperaba, al igual que en procesos judiciales similares, en los que la identificación del taller responsable del material denunciado se lograba invirtiendo el proceso editorial, llegar al origen de la falsificación presionando primero a los distribuidores. ${ }^{15} \mathrm{La}$ detención del anónimo vendedor un día después no logró, sin embargo, esclarecer gran cosa sino que el hecho de que se hospedase y guardase sus pronósticos en la vivienda del otro impresor activo en Logroño, Francisco Delgado, embrollaría el pleito durante años sin que se lograra saber quién era el verdadero responsable. ${ }^{16}$ Por

\footnotetext{
15 Por ejemplo, Fermín de los REYES, «La edición clandestina de las Ruinas de Palmira, del conde de Volney, ¿conspiración o negocio en el Madrid de finales del XVIII?» en Manuel Salamanca, Érika López (ed.), Prácticas de comunicación: la necesidad de escribir en el Madrid del Antiguo Régimen, Madrid, CECEL-CSIC, 2015, pp. 503-536 o Natalia MAILLARD, «El Catálogo de libros de Francisco de Rioja: Cádiz, 1769» en Pedro Rueda, Lluís Agustí (eds.), La publicidad del libro en el mundo hispánico (siglos XVII-XX): Los catálogos de venta de libros y editores, Barcelona, Calambur, 2016, pp. 281-297.

16 Antonio Sanz obtuvo en octubre de 1762 una primera condena de ambos impresores logroñeses, Moreno y Delgado, en base a los antecedentes del primero y a pruebas circunstanciales del segundo (básicamente cuatro: haber alojado al vendedor de pronósticos falsos; haber encargado, en septiembre, a un escultor local el tallado de unos pequeñas decoraciones xilográficas similares a unas aparecidas en los almanaques falsos; haberse encontrado en su poder un pronóstico falso y que él decía haber comprado unos días antes a un vendedor callejero; y, supuestamente, haber impreso, el mismo año que Moreno, en 1760, cuatro resmas de pronósticos falsos). En ningún caso se logró vincular fehacientemente a estos impresores con el suministro de pronósticos ni tampoco se descubrieron los moldes. Cada uno fue multado con 100.000 maravedís (casi 3.000 reales de vellón) más el pago de las costas procesales, la obligación de indemnizar a Sanz por las pérdidas de su privilegio ante la competencia desleal así como la prohibición de dedicarse a su oficio por espacio de un año. Las alegaciones de una parte y otra durante los años siguientes, que retrasaron una condena en firme, y el hecho de que el privilegio de Sanz
} 
aquellos días también se investigó, sin otro resultado, a dos tenderos de Logroño (Mateo Martínez y José Pérez del Notario) a los que el librero Carol, en un nuevo mensaje a Sanz, implicaba en la venta de pronósticos falsos.

Gracias a que el nuevo vendedor ambulante fue considerado una pieza clave en la acusación podemos ofrecer un nuevo perfil para este tipo de vendedores..$^{17}$ Pedro Liñán, como así se llamaba, había nacido en Zaragoza hacia 1731 si bien en los últimos tiempos se le conocía como vecino de Calatayud (en realidad carecía de un domicilio estable). Formado en un ambiente artesanal - había trabajado como zurrador, aquel que curte y adoba las pieles- y con una mínima comprensión lectora - firmó sus declaraciones con letras grandes y separadas - nuestro personaje había llegado al trabajo de coplero como alternativa a la indigencia. Algún accidente lo había dejado incapacitado para las exigencias físicas de su oficio por lo que desde hace poco más de un año venía dedicándose a «vender coplas, pronosticos y otros papeles impresos». Sabemos además que Liñán traficaba con otros productos editoriales semejantes en precio y volumen aunque siempre complementarios a su principal venta, las coplas: «coplas, libritos, novenas y estampas» refiere respecto a sus mercancías uno de sus proveedores, Francisco Delgado; la mujer de este impresor, por su parte, declara haberle vendido en el pasado «coplas, estampas y libritos de devocion y no otro genero de impresiones», ${ }^{18}$ «algunos rezos de santos, relaciones [¿de comedias?, ¿de sucesos?] y otros papeles» así como un buen número de almanaques, «todos doblados», se habían inventariado dentro su zurrón en el momento de su detención. Comprobamos así que, si en el zurrón de Liñán las coplas constituían la única mercancía estable, sus compañeros de ventas podían variar aunque siempre dentro de unas características y un mercado similares. ${ }^{19}$

Prácticas comerciales y circuitos de venta pueden espigarse entre todas estas declaraciones. Los desplazamientos de Liñán, aún dentro de su vagamundeo, se situaron entre las actuales provincias de La Rioja y Navarra identificando sus ejes o puntos de referencia con aquellas localidades donde podía renovar sus mercancías: Pamplona, Calahorra y Logroño. En el año que

finalizara en 1764, año en que aparecen fechadas las últimas diligencias, explican que seguramente ninguno llegara a cumplir la condena (una nota marginal en portada reza «conclusos en rebeldia del Ympresor»).

${ }_{17}$ Gracias a sus tres declaraciones ante las autoridades (3, 12 y 23 de diciembre de 1761) junto con los testimonios de Francisco Delgado (12 de diciembre de 1761), su esposa, Magdalena de Iguruzteta (3 y 12 de diciembre de 1761, 19 de junio de 1762), y una vecina, Teresa Velasco (5 de junio de 1762).

18 Gracias a estas declaraciones podemos conocer parte del fondo editorial del taller de Delgado puesto que -Catálogo Colectivo mediante- no parece haberse conservado ningún ejemplar de estas impresiones.

19 Para una buena definición de estos productos, en su contexto material y editorial, remitimos a Silvia GONZÁLEZ-SARASA, Tipología editorial del impreso antiguo español, tesis doctoral inédita, Madrid, Universidad Complutense, 2013, pp. 132-136, 281, 316-324, 345348, 424-427, 654-674.

Titivillus, ISSN 2387-0915, ISSN-e 2603-9966, 3 (2017), pp. 91-115 
llevaba trabajando como coplero había acudido en tres ocasiones a la imprenta de Francisco Delgado: la primera en los últimos meses de 1760, la segunda en febrero o marzo de 1761, y la tercera, en la que acabó detenido, a principios de diciembre de este año. Aunque existe un vacío para el periodo estival achacable a un cambio de ruta o de proveedor (el zaragozano también había acudido en una fecha indeterminada al taller de Moreno) o un cambio de actividad (quizás como jornalero agrícola) advertimos en las visitas a la capital riojana cierta regularidad temporal — de 3 a 4 meses-.

Conocemos con algún detalle la ruta seguida por nuestro vendedor en los meses anteriores a su última visita a Logroño gracias al interés de las autoridades por saber dónde compró los almanaques inventariados en su zurrón: 19 pronósticos auténticos, 14 que «son distintos y parecen contrahechos» más otros 54 impresos en Pamplona, estos últimos correspondientes a un almanaque compuesto por el famoso Torres Villarroel y que por características materiales - 16 páginas en octavo- ${ }^{20}$ y similares contenidos podía competir desde la ilegalidad con el editado por Sanz. Siguiendo la declaración de Liñán sabemos que pasó, en un momento sin especificar pero no anterior a finales de agosto o principios de septiembre (tiempo en que comenzaban a distribuirse esta obra), por Pamplona. Allí pudo comprar, en el taller de José Miguel Ezquerro (prueba de la responsabilidad de este impresor en esta edición ilegal), ${ }^{21} 5$ manos de pronósticos por 10 reales de vellón.

Después de Pamplona se encontró en Lodosa, una población del suroeste navarro cercana a tierras riojanas, con un «marchante» a quien no conocía y que le vendió, por 9 reales en total, 3 manos del pronóstico falsificado bajo el convencimiento de ser original. Su último destino conocido, antes de Logroño, fue Calahorra, una importante población del este riojano gracias, sobre todo, a su condición de sede diocesana. Allí pudo renovar sus mercancías por última vez con la compra al librero local, Juan Carol, de una mano de pronósticos, esta vez, legítimos, al precio de «treinta y dos cuartos»,

\footnotetext{
${ }^{20}$ Solo se conoce un ejemplar de esta edición, conservado en la catedral de Pamplona. Ministerio de EduCACIÓN, Catálogo Colectivo del Patrimonio Bibliográfico Español, Madrid, Ministerio de Educación, Cultura y Deporte, c. 1990, http://ccpb_opac.mcu.es /CCPBopac (CCPB), 000954330-9 [Consulta: noviembre de 2016].

${ }^{21}$ Los Ezquerro contaba con un largo historial en la edición de almanaques. Ya en 1745 el cabeza de familia, Pedro José, había logrado el privilegio de edición de este tipo de obras para el reino de Navarra, un monopolio enseguida contestado por Antonio Sanz. El conflicto se solventó en algún momento de los cincuenta cuando los Ezquerro lograron del madrileño la cesión de su privilegio para el territorio navarro si bien para 1760 esta cooperación se había roto. Javier ITÚRBIDE, Los libros de un reino. Historia de la edición en Navarra (1490-1841), Pamplona, Gobierno de Navarra, 2015, anexo CD, pp. 246-249. Que Ezquerro hijo editara el almanaque de Torres Villarroel sin indicar su participación en el pie de imprenta es demostrativo, no solo de su ilegalidad, sino de que seguían desafiando a Sanz.
} 
casi 4 reales. ${ }^{22}$ Ocho días después, el 2 de diciembre, y a una velocidad media de $5,4 \mathrm{~km}$ (en el supuesto de seguir una línea recta), Liñán entraba en Logroño. Entre cada una de estas poblaciones había parado en distintos pueblos despachando la mayor parte de sus ventas.

\begin{tabular}{|c|c|c|c|c|c|c|}
\hline Vendedor & Comprados & $\begin{array}{l}\text { Precio de } \\
\text { costo total }\end{array}$ & $\begin{array}{l}\text { Precio de } \\
\text { costo por } \\
\text { mano }\end{array}$ & $\begin{array}{l}\text { Precio de } \\
\text { costo por } \\
\text { ejemplar }\end{array}$ & \multicolumn{2}{|c|}{ Revendidos } \\
\hline $\begin{array}{l}\text { José Miguel } \\
\text { Ezquerro }\end{array}$ & $\begin{array}{c}5 \text { manos }= \\
125 \\
\text { ejemplares }\end{array}$ & $\begin{array}{c}10 \mathrm{rs} \\
(340 \mathrm{~ms})\end{array}$ & $\begin{array}{c}2 \mathrm{rs} \\
(68 \mathrm{mrv})\end{array}$ & $2,72 \mathrm{~ms}$ & 71 ejemplares & $56,8 \%$ \\
\hline $\begin{array}{l}\text { Comerciante } \\
\text { desconocido }\end{array}$ & $\begin{array}{c}3 \text { manos }= \\
75 \text { ejemplares }\end{array}$ & $\begin{array}{c}9 \mathrm{rs} \\
(306 \mathrm{~ms})\end{array}$ & $\begin{array}{c}3 \mathrm{rs} \\
(102 \mathrm{~ms})\end{array}$ & $4,08 \mathrm{~ms}$ & 61 ejemplares & $81,3 \%$ \\
\hline Juan Carol & $\begin{array}{c}1 \text { mano }=25 \\
\text { ejemplares }\end{array}$ & $\begin{array}{c}3 \mathrm{rs} \mathrm{y} 26 \mathrm{mv} \\
(128 \mathrm{mv})\end{array}$ & $\begin{array}{c}3 \text { rs y } 26 \mathrm{mrv} \\
(128 \mathrm{~ms})\end{array}$ & $5,12 \mathrm{~ms}$ & 6 ejemplares & $24 \%$ \\
\hline
\end{tabular}

Tabla 1. Compra-venta de pronósticos por Pedro Liñán

Una comparativa de los anteriores datos — número de ejemplares, precios, ventas - se presta a una serie de valoraciones:

- Nuestro vendedor aprovechaba cualquier ocasión (fuera un impresor, un librero o una oferta en el camino) para renovar sus mercancías, suponemos que acorde a cómo hubiesen ido sus ventas. Vemos también como Liñán, a la hora de renovar el surtido, no hacía más distinciones entre una edición de almanaque u otra que el precio (era muy consciente de cuanto le había costado cada mano). Las compras de Liñán así lo demuestran, siendo el producto más barato, el almanaque pamplonés, el que recibió una mayor inversión - 5 manos - aunque dicha cantidad pudo ser estimulada por su reciente impresión y a que la demanda de este título estaba casi virgen. Iguales condicionantes, aunque en sentido contrario (un precio por un unidad elevado y una demanda ya explotada) pueden explicar la pequeña compra del verdadero almanaque.

- Las compras de Liñán nos orientan sobre el nivel de sus inversiones para un impreso, tanto máximas (5 manos por 10 reales de vellón) como mínimas (1 mano por casi 4 reales). Interesa también el hecho de que las ventas al por mayor de estos impresos se produjeran en manos, como el caso de Liñán, o en resmas, como sucede con el

\footnotetext{
${ }^{22}$ Los «cuartos» eran piezas con valor de 4 maravedíes. Véase José María de FRANCISCO, Los miembros del Consejo de Hacienda (1722-1838) y organismos económicos-monetarios, Madrid, Castellum, 1997, p. 354.
}

Titivillus, ISSN 2387-0915, ISSN-e 2603-9966, 3 (2017), pp. 91-115 
tendero de Haro. El empleo de estas unidades de cuenta nos señala que la preparación de estos impresos de cara al cliente (al no precisar de encuadernación y coincidir la extensión de cada ejemplar con un pliego justo) corría a cuenta del vendedor minorista.

- En cuanto al precio de costo por ejemplar encontramos sustanciales diferencias para impresos de similares características y que no solo pueden achacarse al empleo de materiales - papel, tipos- de menor o mayor calidad, como así sucedía en las falsificaciones del privilegiado (visible en el oscurecimiento del papel o unos tipos y tacos gastados). El mejor precio por unidad lo encontramos en el almanaque pamplonés (su precio es casi la mitad del legítimo) y que se explica gracias a dos causas principales: el hecho de que su impresor no tuviese que costear la cesión del privilegio y que su distribución contara con un número mínimo de intermediarios.

- Respecto a la ventas efectuadas por Liñán el hecho de que adquiriera los pronósticos en diferentes momentos impide que sepamos cuál de ellos era el más vendido o si Liñán los ofertaba a diferentes precios (sabemos que, al menos, el almanaque de Sanz estaba tasado para su venta a 6 maravedís). Aún así se confirma la buena venta del pronóstico pamplonés — con el mayor número de ejemplares vendidos, resultado también de llevar más tiempo en oferta- si bien el hecho de que solo se hayan vendido poco más de la mitad de la compra inicial de Liñán indica cierto fracaso como inversión. Mayor éxito comercial conoció el almanaque falsificado, con más del $80 \%$ de sus ejemplares vendidos, y que sugiere que este almanaque, debido a su autor o por su editor, gozaría de mayor credibilidad en tierras castellanas frente al editado en Pamplona, el cual, no obstante, se preciaba en portada de «sirve para todos los Reynos de España». Estas últimas cifras también pueden explicar que Liñán procurara proveerse de más pronósticos parecidos y que por ello adquiriera en el último momento una mano de legítimos, aun reduciendo bastante su margen de beneficio.

- Si algo demuestran estas cifras es el rotundo triunfo comercial de las ediciones ilegales frente a la comercializada por Sanz: no solo llegaban antes al mercado, tanto urbano y rural, gracias a su cercanía a los vendedores, y con mejor precio (de las 9 manos compradas por Liñán tan sólo una había sido impresa por Sanz), sino que acaparaban el grueso de las ventas (de los 87 ejemplares vendidos solo 6 correspondían a la edición legítima).

Destacar finalmente como el contacto de Delgado con Liñán trascendía el mero acuerdo comercial al existir una relación de confianza, mutuamente beneficiosa para ambos. El coplero zaragozano, en sus visitas a Logroño, pasaba a alojarse en la vivienda ( $\mathrm{y}$ a la vez taller) de este impresor, donde disfrutaba, por una noche al menos, de un lugar donde dormir y comer -en su última visita pudo desayunar unas «sopas»- Mucho mejor que su otra 
alternativa, el «hospicio» local. Esta confianza mutua incluía también la posibilidad de contar con crédito para comprar impresos: así Liñán dejó a deber a Delgado 6 «pesetas» en su segunda visita, una modesta inversión —al cambio 24 reales de vellón-23 que terminaría devolviendo unos cuantos meses después junto con el adelanto de otras 2 pesetas para coplas. Con estas concesiones - seguramente repetidas con otros buhoneros- el tipógrafo logroñés se aseguraba una eficaz distribución de su producción al consolidar una red propia de venta ambulante.

El comercio de estos produtos no reportaba grandes ingresos para Liñán, solo lo justo para subsistir de forma errante. Aunque la fuente es parca en cuanto a ahorros o beneficios si menudean la referencias a su pobreza: el mismo Liñán, además de confirmar que «anda vago», se presentará como «pobre de solemnidad»; la mujer del impresor Delgado justifica haberle alojado "por caridad porque no fuese al hospicio»; incluso el propio Sanz, desde Madrid, tuvo conocimiento de que «su pobreza y miseria es notoria», razón por la que accedió a retirar los cargos contra Liñán y a que este fuese liberado de la cárcel con la advertencia de no volver a vender impresiones ilegales, momento —24 de diciembre de 1761 - en el que se enfría para siempre su rastro.

\section{Madrid-Toledo, 1779}

El segundo caso nos remite a 1779, con la figura de Juan Carvallo. Su detención por las autoridades de Illescas (municipio al norte de Toledo y limítrofe con la actual comunidad de Madrid) se produjo en cumplimiento de la Real Ordenanza de 7 de mayo de 1775 , en la cual se regulaba el reclutamiento forzoso y anual de aquellas ugentes ociosas, y sobrantes, que vivan distraídas, baldías, y malentretenidas, sin aplicación al trabajo» bajo un doble objetivo: complementar la contribución a los reemplazos del ejército por parte de las quintas y el alistamiento voluntario al tiempo mismo que se frenaba el potencial aumento de la delincuencia y de los gastos sociales. ${ }^{24}$

Similares fines ocupaban, un 26 de junio de 1779, los pensamientos del licenciado Pedro Vicente de Ullauri, a la sazón, corregidor de Illescas y, por tanto, responsable de los asuntos militares en esta jurisdicción. Ese día, por la tarde, pasó a controlar, en compañía de un subalterno, el trasiego de forasteros llegados a su villa por el «cam[in]. de Madrid». ${ }^{25}$ De forma paralela

\footnotetext{
${ }^{23}$ Una peseta provincial o corriente se cambiaba por cuatro reales de vellón. FRANCISCO, Los miembros..., p. 353.

${ }^{24}$ Ordenanza de S.M. en que se previene y establece el recogimiento de vagos y mal-entretenidos por medio de levas anuales, y se encarga a las Justicias Ordinarias... el orden judicial... Madrid, Pedro Marín, 1779 .

25 ArChivo de la Real Chancillería de Valladolid. Pleitos criminales, caja 378/5. En adelante nos remitiremos a este documento para evitar múltiples citas.
}

Titivillus, ISSN 2387-0915, ISSN-e 2603-9966, 3 (2017), pp. 91-115 
otro grupo, conformado por los dos Alcaldes de Hermandad más un escribano, completaban el cerco por otra parte. En la ermita de San Cosme, situada a las afueras y al borde del camino (entonces arruinada y hoy ya desaparecida), las pesquisas dieron resultado al encontrar descansando en su portal a «tres hombres el uno ziego que traia otro viejo p[o].r lazarillo, y el otro era también biejo con sus Mugeres $\mathrm{q}[\mathrm{u}]$.e traian cosas de Quincalla, y otras menudenzias». Los dos primeros, uno por defecto físico y otro por edad, fueron inmediatamente descartados para la leva mientras que el tercero, al poder demostrar su estado de matrimonio, fue dejado marchar. Lamentablemente no se detallaron las mercancías ni equipaje de ninguno si bien, con probabilidad, entre ellas se contaban impresos.

La tarde parecía echada a perder para Ullauri y adláteres si bien, desde la misma ermita, pudieron advertir la llegada de un nuevo forastero, «un mozo

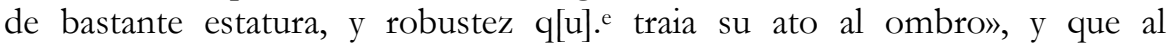
momento despertó sus sospechas. Las autoridades salieron a su encuentro y procedieron a interrogarle. El aludido, todavía anónimo, respondió ser natural de Portugal, de cuyo ejército había desertado; residir en Madrid, en la calle de Atocha; y que su último destino había sido Esquivias, un pueblo cercano (a siete kilómetros), adonde se había dedicado a vender los «romanzes y Coplas» que llevaba en su hato. El corregidor, ante la «mala traza de dicho mozo» y la carencia de un certificado acreditativo de su forma de vida firmado en su lugar de residencia, decidió que pasara a la cárcel local para someterlo a un interrogatorio más exhaustivo. Una vez allí, encerrado en una celda, el escribano pasó a detallar las pertenencias del preso: «unos tres ô cuatro legajos de Papel q[u].e Dijo ser Coplas y estampas, diferentes ebillas biejas, abujas, alambre y un poco de Ropa de vestir y zincuenta y nueve rr[eale]. en Plata y vellon».

Aunque no se detallan los títulos de los impresos su clasificación como «romances», «coplas»y «estampas» los identifican, en cuanto a los dos primeros, como conspicuos representantes de la literatura efímera o de cordel. Por lo que toca a las estampas, otro producto que no faltaba en los surtidos de impresores y libreros, seguramente serían de temática devocional. Incluso, pese a que el escribano de Illescas no se detiene en contar el número exacto de los impresos del detenido, podemos calcularlo en base al hábito seguido entre sus pares invidentes de Madrid (y al igual que en el caso logroñés) de adquirir los impresos por mano (unos 25 pliegos justos) ${ }^{26}$ y que vendría a corresponderse con esos «tres o cuatro legajos de papel». Así, tomando como base la cantidad de 3 manos o 3 legajos y apercibidos de que cada mano podía contener entre veinticinco o cincuenta ejemplares —en función de que los impresos tuvieran entre ocho o cuatro páginas (para los romances y coplas) o que cada estampa consumiera entre medio y un pliego completo-, nuestro detenido llevaba a la venta en el momento de entrar en Illescas entre 75 y 150 ejemplares de un número diferentes de títulos o grabados desconocidos. Una

${ }^{26}$ BOTREL, Libros..., pp. 122-123. 
baja cifra que podría explicarse por hallarse el vendedor al final de su circuito de venta y que se corroboraría por los casi 60 reales que ahorraba, un capital poco importante a tenor del salario de un trabajador agrícola de la época pero demostrativo del coqueteo de estos personajes con la pobreza. ${ }^{27}$

Al día siguiente, 27 de junio, el corregidor pasó a tomar declaración al detenido con objeto de dilucidar sus circunstancias y decidir, en consecuencia, su estado de «vago». Las protocolarias preguntas sobre su origen y vecindad actual, oficio, estado civil y edad nos ofrecen una primera biografía de nuestro personaje. Por sus respuestas sabemos que se llamaba Juan Carvallo, natural del pueblo portugués de Constantim, ${ }^{28}$ de estado soltero, y que había abandonado su país hacia ya casi dos años por haber desertado del ejército luso dirigiéndose, en aquel entonces, a Madrid. En la capital se había empleado, para subsistir, en «vender p[o].r los Pueblos [cercanos] Papel pintado, Coplas, y Romances, hazer rosarios y componer ebillas». Completaba este trato con la adquisición de «plata vieja» por estas poblaciones. Durante estos dos años había regresado en varias ocasiones a Madrid para reponer sus mercancías. Una corrección posterior de la edad, debido a un olvido del escribano, nos hace saber que sumaba «de veinte y siete â veinte y ocho años poco mas ô menos».

Ante el interés de las autoridades por obtener alguna justificación de su modo de vida, de acuerdo a lo dispuesto por la Ordenanza de $1775,{ }^{29}$ Carvallo proporcionó varios nombres; explicó que en Madrid se alojaba en la calle de Toledo, en una «Posada de Gentes» de un tal Cayetano (no recordaba el apellido) al tiempo que acudía a la imprenta de Andrés de Soto, en la calle de Bordadores, enfrente de la parroquia de San Ginés, a «comprar los Romances, Coplas, Cartillas y demás», así como a la lonja de un comerciante, un tal «sobrino de Juan Antonio», en la Plaza Mayor, en la que se surtía de «Cosas de aguja, alambres, papeles pintados y otras». Esta corta lista de conocidos, a los que solo había tratado superficialmente y por motivos estrictamente profesionales (en ninguno da las señas completas con la salvedad del tipógrafo), indica claramente la fragilidad de su círculo social.

Las referencias facilitadas por el portugués fueron examinadas por las autoridades sin demora. En una carta, depositada en el correo el día del

${ }^{27}$ Se ha estimado para 1777 un jornal diario de 1,36 pesetas, al cambio, poco más de cinco reales y medio. José Miguel MARTíNEZ, El nivel de vida en la España rural, siglos XVIII-XX, Alicante, Universidad, 2002, p. 661.

${ }^{28}$ La falta de más datos sobre su lugar de nacimiento nos impide identificarlo con una de las dos «freguesias»-parroquias o barrios- hoy existentes bajo este topónimo, ambas en el norte de Portugal, la primera comprendida en el «concelho» de Miranda de Douro, la otra en el de Vila Real.

${ }^{29}$ El artículo XIV establecía que si el acusado «alegáre estár dedicado à la labranza, ha de demostrar la yunta, y tierras propias, ó agenas en que labra, con las demás determinaciones oportunas, para averiguar la verdad; y lo mismo [...] si alegáre estár dedicado á oficio, justificando el taller propio, ó ageno, y el maestro, ú oficiales, con quienes trabaja continuada $[\ldots] \gg$.

Titivillus, ISSN 2387-0915, ISSN-e 2603-9966, 3 (2017), pp. 91-115 
interrogatorio, el corregidor de Illescas detallaba la declaración del preso y solicitaba colaboración a Madrid para comprobar sus antecedentes. Poco después, el 3 de julio, su petición era atendida por don Francisco García de la Cruz, alcalde de Casa y Corte; ese mismo día este hacía llamar a su presencia a los tres conocidos de Carvallo. Conocidos entre comillas pues ninguno lo recordaba. Cayetano Verdugo Casado, el posadero (39 años y vecino en la calle de Toledo), declaró haber hospedado hacia dos meses, durante ocho días, a un portugués, un tal Juan, dedicado a la venta de «relicarios, Pendientes, y otras friolerillas de Quincalla». Recordaba además su edad —entre 36 y 40 años-, su indumentaria, un «Calzon y Chupa de Ante, Botones de metal dorado», así como su intención de marchar a Barcelona. Evidentemente estos detalles no casaban con nuestro sujeto.

La declaración de los otros dos testigos, el impresor Andrés de Sotos (con 54 años) y el comerciante José Ceballos (20 años), fue más decepcionante aún. Ambos rechazaron conocer al sujeto excusando su negativa en que «a sus respectivas tiendas iban varios sujetos a comprar y $\mathrm{q}[\mathrm{u}] . .^{\mathrm{e}}$ no tomavan $\operatorname{raz}[\mathrm{o}] .{ }^{\mathrm{n}}$ de quienes fuesen». Estas respuestas, aunque escuetas, nos permiten ver que en la comercialización de lotes de impresos efímeros y quincallería participaban, a menudo, los mismos agentes y que estas mercancías se regían por similares usos comerciales: por su pequeño valor y por pagarse al contado no quedaban registradas en ninguna contabilidad. Asimismo es interesante señalar, por lo tocante al impresor Sotos, como las existencias de su negocio eran capaces de satisfacer enteramente las necesidades de un pequeño buhonero (Carvallo, en sus dos años como vendedor de impresos, no parece haber acudido a otro impresor o, al menos, no lo cita en su defensa).

Es de lamentar, finalmente, que no se nos ofrezcan más detalles sobre Andrés de Sotos. A tenor de su declaración (el número de buhoneros que compraban en su taller debía ser alto al no ser capaz de individualizarlos) su negocio parece aspirar al calificativo de «emporio del género de cordel» con el que recientemente se han caracterizado algún taller valenciano del XVIII que tenía en la masiva impresión de este tipo de literatura, después comercializada a nivel regional e incluso nacional, su principal, y casi única, fuente de ingresos. ${ }^{30} \mathrm{Si}$ casi nada sabemos de Sotos, librero de formación y a quien encontramos trabajando en Madrid al frente de su propio taller durante casi toda la segunda mitad del siglo dieciocho (según sus pies de imprenta datados, entre 1764 y 1797), el hecho de que una parte importante de sus trabajos catalogados en el Catálogo Colectivo sean títulos populares de mínima extensión - romances, relaciones de sucesos, comedias más géneros afines- y que compaginaría con la recepción de encargos más serios, ${ }^{31}$ así como que fuera

\footnotetext{
${ }^{30}$ Juan GomIS, «Un emporio del género de cordel. Agustín Laborda y sus menudencias de imprenta (1743-1776)» en Antonio Castillo (ed.), Culturas del escrito. Del Renacimiento a la contemporaneidad, Madrid, Casa de Velázquez, 2015, pp. 239-250.

31 Como ejemplo, «Primera parte de los romances de doña Juana de Acevedo» (CCPB 000847627-6), «El año del gallo: obra muy graciosa para reir, y pasar tiempo...»
} 
corresponsal, en los sesenta y setenta, del impresor valenciano Laborda (especializado en este tipo de impresos) ${ }^{32}$ confirman este extremo.

Volviendo a Carvallo, la llegada de las anteriores declaraciones a Illescas no ayudó en modo alguno a su defensa pues vinieron a reforzar los prejuicios de las autoridades locales acerca de su estado de vagamundeo más el agravante de haber mentido en su testimonio. El portugués, en una nueva declaración fechada el 7 de julio, argumentó razonablemente la falta de referencias sobre su persona en base a, primero, haberse hospedado únicamente unos pocos días en la citada posada; segundo, en que no era de extrañar que tanto el tipógrafo como el comerciante no lo recordaran debido a que «como son tiendas entran muchos â comprar». Asimismo rehusó identificarse con el portugués descrito por el posadero puesto que tenía menos edad y vestía ropas distintas (ilustrativas de su pobre condición): «el Calz[o]. ${ }^{\mathrm{n}}[\ldots]$ es de Paño pardo bas[tan].te traido con algunos agujeros, y la Chupa de paño arretinado, quasi perdido el Colon». Sus esfuerzos resultaron estériles pues el corregidor de Illescas, tras examinar las declaraciones y desechar las del portugués por «falsas», declaró al día siguiente su aptitud para el servicio de las armas en base a carecer de ocupación y a cumplir, por edad y estatura, con las condiciones físicas exigidas, algo que después confirmó un examen médico.

La suerte de Carvallo nos resulta desconocida. Todo indica que reanudó, de manera forzada, su carrera militar. El corregidor ordenó que, una vez realizado el examen médico del preso, fuera conducido hasta Toledo, donde quedaría a disposición del oficial responsable de la leva. Además, en conformidad al artículo XXXIV de la Ordenanza, envió una copia de este procedimiento a la Chancillería de Valladolid para su aprobación, documento con el que ahora trabajamos y cuya última anotación, firmada el 18 de agosto de 1779, nos indica el visto bueno de la actuación del corregidor illescano.

\section{Córdoba, Sevilla, Huelva, 1803}

El tercer caso de comercio ambulante de impresos que presentamos en este trabajo nos traslada al occidente andaluz a principios del siglo diecinueve, casi dieciocho, si bien las características de la documentación consultada difieren de las anteriores: su origen no se encuentra en la intervención de una autoridad civil sino en la actuación de la Inquisición sevillana, entre 1803 y 1807, sobre un veterano negocio de librería e imprenta hispalense, el de la familia de origen cántabro Hidalgo, y que responde a una intensificación de la

(000847937-2), «Gozos de la Virgen de Gracia de Mahora»(000062495-0), «Comedia famosa La vida es sueño de D. Pedro Calderon de la Barca» (000714116-5) o «Relacion donde noticia el valiente y esforzado cavallero Roldan a su tio el emperador Carlo Magno...» (000847699-3).

32 GOMIs, Menudencias..., pp. 234-235, 258.

Titivillus, ISSN 2387-0915, ISSN-e 2603-9966, 3 (2017), pp. 91-115 
vigilancia por el Santo Oficio desde el estallido revolucionario en Francia. ${ }^{33}$ Ante la desaparición de la mayor parte del archivo de este tribunal hemos trabajado con un resumen del proceso remitido como alegación a la Suprema de Madrid. ${ }^{34}$

En este proceso advertimos dos etapas: una primera, la que nos interesa, en la que se recogen brevemente los antecedentes de los Hidalgo en la impresión y venta de algunas estampas prohibidas, más otra en la que la Inquisición recoge una serie de delaciones, tanto de clientes religiosos como laicos, sobre la venta o presencia de impresos prohibidos en esta tienda al tiempo que cotejaban las listas de libros llegados a nombre de estos libreros en la aduana. ${ }^{35}$ Pese a que Hidalgo recibió un aviso en 1805 sobre sus «repetidos excesos» nuevas pruebas explican que a principios de 1807 la Inquisición local pasara de las palabras a los hechos: se le declaró «incurso en excomunion mayor», se le impuso una multa de 200 ducados y se acordó proceder a una minuciosa inspección de su librería

Los orígenes de esta condena se retrotraen unos años antes. En 1803 dos denuncias, casi simultáneas, pusieron sobre aviso a la Inquisición sevillana respecto a la comercialización de estampas prohibidas en varias poblaciones onubenses. Si hacemos caso al resumen del proceso este tribunal tuvo un primer conocimiento a partir de una carta enviada por uno de sus comisarios, el fraile Antonio Maceda, el 18 de octubre. Según recogía este religioso tres días antes había recalado en Villalba del Alcor (población de alguna importancia al este de la provincia de Huelva y cercana a tierras sevillanas) un «biejo vendiendo Romances y otros papeles con varias estampas». Maceda, revisando las mercancías de este buhonero (quizás en calidad de cliente),

\footnotetext{
33 Poco sabemos de esta familia o de sus negocios aunque su papel se adivina importante. Por los pies de imprenta sabemos que el patriarca de los Hidalgo, Francisco Antonio, formó compañía, al menos desde 1781, con un veterano tipógrafo hispalense, Manuel Nicolás Vázquez, activo desde la década de los cincuenta en la calle Génova. Tras la muerte del primer Hidalgo la imprenta se traspasa a su viuda y herederos hasta que en el cambio de siglo (1800) aparece al frente de la misma un sobrino, José Hidalgo. De ella se ha dicho que «fue una imprenta importante, de una gran actividad, con su correspondiente serie de comedias». Véase Francisco AguILAR, Impresos sevillanos del siglo XVIII, Madrid, CSIC, 1974, p. 20. Los Hidalgo compaginaron el taller con un activo comercio de libros, en conexión con otros centros peninsulares y también el extranjero. Sabemos que en 1785 el primer Hidalgo, todavía en compañía con Vázquez, reclamaba ante el Consejo de Castilla unos libros procedentes de Venecia y Lyon e incautados en la aduana. AHN. Consejos, 5551, exp. 69. Además una colección de cartas de José Hidalgo, remitidas y recibidas entre 1804 y 1826, nos desvela sus negocios con libreros e impresores de Cádiz, Córdoba, Valencia y Madrid entre otros. Biblioteca Nacional de España, R/62732.

34 AHN. Inquisición, 3731, exp. 147. En adelante nos remitiremos a este documento para evitar múltiples citas.

35 Parte de este material ya ha sido trabajado, aunque de forma bastante chapucera (se inventa, sin más datos que la coincidencia de apellido, la presencia de nuestro Hidalgo a Cuba y su posterior paso a México), por Marcela GONZÁLEZ CALDERÓN, La imprenta en la peninsula del Yucatán en el siglo XIX, tesis doctoral inédita, México, CIESAS, 2014, p. 85.
} 
localizó una grabado que despertó sus sospechas. El motivo de las mismas, «una del Cristo de la Expiacion con la revelac[io]. ${ }^{\mathrm{n}}$ de Sta Brigida», no aparece recogida en el último índice inquisitorial publicado —el de 1790 — aunque entraría dentro de aquellas imágenes, en variados soportes, «a que se atribuyen efectos que penden de sola la voluntad» o que «sean en irrision y escarnio de los Santos Sacramentos, ó de los Santos [...]».36

Si bien el interrogatorio al que Maceda sometió al anónimo vendedor hubo de abundar en detalles de naturaleza personal el resumen con el trabajamos solo recoge el supuesto origen de estas estampas: «de Cordoba de la Ymprenta de un tal Felix». Decimos supuesto porque la inclusión de esta incautación dentro de un proceso a José Hidalgo y el hecho de que no conozcamos ningún tipógrafo activo en Córdoba bajo este nombre y en estas fechas $^{37}$ nos inclina a pensar que el vendedor intentó despistar a un interrogador mediante unas señas falsas y así ocultar la responsabilidad de los Hidalgo como los verdaderos proveedores. Otra posibilidad puede ser un error de copia pues sí que existió para estas fechas un impresor bajo este nombre pero no en Córdoba sino en Sevilla — Félix de la Puerta— ${ }^{38}$ si bien quedaría todavía por explicar la razón del por qué se incluyeron estas pesquisas entre los antecedentes de José Hidalgo.

Es interesante destacar cómo una vez más nos encontramos a un buhonero que acudía a surtirse a un único proveedor, sea un impresor sevillano o cordobés. Por lo demás no se facilitan más datos aunque es interesante considerar su avanzada edad (para esa época) y que se tratara de un buhonero especializado en la comercialización de literatura de cordel - los romances - e impresos afines, caso de las estampas devocionales. Con seguridad representó un perfil bastante habitual entre estos vendedores ambulantes. Por lo que toca a otros aspectos de la comercialización ambulante, como el circuito seguido por el vendedor o el volumen de mercancía vendida, la actuación posterior del fraile en Villalba ofrece algunos datos.

Maceda, conocida la naturaleza prohibida de la estampa, retuvo al vendedor las que todavía no había vendido y pasó, al día siguiente, a anunciar desde la parroquia local la obligación de quienes las hubiesen adquirido de entregarlas a la autoridad. Al parecer obtuvo unos pobres resultados - tan solo 11 estampas que se sumarían a las ya incautadas y de las que no se especifica el número- pese a saber que «habia vendido muchas en el Pueblo». ${ }^{39}$ Mejores frutos ofrecieron tres pueblos próximos a Villalba gracias

\footnotetext{
${ }^{36}$ Indice ultimo de los libros prohibidos y mandados expurgar, Madrid, Antonio de Sancha, 1790, pp. XIX, XXII.

${ }^{37}$ El Catálogo Colectivo no cita ningún Félix entre la producción cordobesa de la época.

38 Activo al menos desde 1791, fecha de su primer impreso conocido. AguILAR, Impresos..., p. 14.

39 Este pequeño número, aun teniendo presente que Maceda interrumpió la venta, nos hace sospechar un error en la copia del documento.
}

Titivillus, ISSN 2387-0915, ISSN-e 2603-9966, 3 (2017), pp. 91-115 
al aviso - acompañado de un ejemplar de la estampa - remitido a los comisarios de la Inquisición allí residentes. El hecho de que el anónimo buhonero hubiese vendido en estas poblaciones «un sin fin de ellas», como se declara en el resumen, justificaba las pesquisas. Poco después le fueron remitidas 77 estampas junto con una manuscrita (un curioso detalle acerca de las formas de transformación del producto impreso) desde Manzanilla, 268 ejemplares desde Paterna del Campo más 55 llegadas desde Escacena del Campo; en total, y si los números son correctos, se recogieron más de cuatrocientas estampas en tan solo cuatro pueblos que, para finales del dieciocho, sumaban una población total de más de 7.000 personas. ${ }^{40}$

La anterior cifra, ilustrativa del fuerte consumo de estos productos impresos (interesante habría sido conocer las venta paralela de los romances y otros materiales impresos por el mismo buhonero para medir los niveles de lectura), también es indicativa de la potencia de las zonas rurales como salida comercial para el stock de impresores y libreros. Igualmente, aunque las limitadas pesquisas del comisario Maceda nos impiden reproducir la ruta seguida por el buhonero, sí podemos ver cómo se dirigía de este a oeste y como hacía su principal comercio en los grandes pueblos presentes en el camino.

El segundo personaje estudiado toma la información de un memorial elevado a la inquisición hispalense por un tal Juan Latur en calidad de afectado por la incautación de unas estampas y por cuya pérdida —así como por el tiempo en el que estuvo retenido- exigía una indemnización. Francés, de más de sesenta años, viudo con tres hijos y residente en Sevilla era su tarjeta de presentación. Estos pocos datos nos reflejan otro perfil de vendedor. Su origen nos hace relacionarlo con el protagonismo de la buhonería francesa en el mercado peninsular durante buena parte de época moderna, con frecuencia, partícipe en el mercadeo del impreso, y que en el dieciocho aún mantuvo su vigor. ${ }^{41}$ No creemos, con todo, que Latur perteneciera, por apellido y la escasa entidad de su negocio, a una de esas familias oriundas del Delfinado y especializadas en el comercio del libro a escala europea. ${ }^{42}$ Su elevada edad, una complicada situación familiar y un limitado arraigo hacen ver en su dedicación a la venta de estampas una vía de escape.

Latur había acudido a surtirse, a mediados de septiembre, a la imprenta de la viuda de Hidalgo. En ella adquirió seis resmas - 120 manos- de una sola

\footnotetext{
40 Escacena sumaba 1.610 habitantes; Manzanilla, 1.841; Paterna, 1.714; Villalba, por su parte, 2.034. Cifras tomadas del Censo de Floridablanca 1787. Comunidades Autónomas Meridionales, Madrid, Instituto Nacional de Estadística, 1987, pp. 16-17.

${ }^{41}$ Clive GrIfFIN, «Itinerant Booksellers, Printers and Pedlars in Sixteenth-Century Spain and Portugal» en Myers, Fairs..., pp. 43-59 y LOPEZ, «Gentes y oficios...», pp. 165-166.

${ }^{42}$ Véase Laurence FONTAINE, Histoire du colportage en Europe (XVe-XIXe siècle), París, Albin Michel, 1993, pp. 51-94.
}

Titivillus, ISSN 2387-0915, ISSN-e 2603-9966, 3 (2017), pp. 91-115 
estampa —la «oracion del Santo Sepulcro» -43 por 340 reales (a 3 reales la mano). Tanto la elevada inversión inicial como que se produjera en una sola obra —al parecer su única compra (recordar sus palabras: «que habiendo comprado una porción de estampas a la viuda de Hidalgo para venderlas por los lugares») - así como el hecho de que su transporte exigía necesariamente la ayuda de una caballería nos hacer ver en Latur un intermediario bastante atípico dentro de estas redes ambulantes a tenor de las cifras manejadas en los anteriores casos. O bien era un recién llegado a este tipo de ventas, y de ahí su ingenuidad en invertir una parte importante de su capital en un solo tipo de impreso, cuyo embargo por la Inquisición lo dejaba sin «otra cosa con que mantener à su familia»; o bien comerciaba con otros productos. La compra del francés no significó nada para el librero Hidalgo porque, como este aduciría tiempo después, el grueso de la tirada de esta estampa había sido vendido «a los ciegos que fueron a buscarlas».

Nada dice la declaración acerca de la ruta seguida por Latur hasta que llega, a mediados de noviembre, a la villa onubense de Trigueros (distante de la capital hispalense, en línea recta y desde el oeste, unos 75 kilómetros). Las ventas, en este tiempo, no habían sido buenas —en sus palabras «ha vendido muy pocas»— al haber colocado solo unas treinta manos (unas 750 ó 1.500 estampas dependiendo de si cada ejemplar consumía medio o un pliego completo). Una vez en Trigueros, y tras haber logrado vender un centenar y medio de esta estampas, fue denunciado ante la Inquisición y hecho preso por más de dos semanas. Los grabados restantes (los incautados más los devueltos por los compradores locales) terminaron quemados.

\section{Conclusiones}

Los vacíos que hoy presenta nuestro conocimiento del comercio ambulante de impresos en época moderna justifican un toque de atención - con el atenuante del complicado acceso a las fuentes primarias- así como el calificativo de «invisibles» con que hemos bautizado a sus protagonistas. ${ }^{44}$ Investigar en sus perfiles y prácticas comerciales se revela básico pues constituían un engranaje indispensable en la comercialización de los fondos de

\footnotetext{
${ }^{43}$ La Inquisición vigilaba hasta siete registros bajo este título, todos ellos variantes de una misma historia, el hallazgo ficticio por un sacerdote de una oración en el sepulcro de Jesucristo o en el altar de San Pedro. Como era habitual se aseguraba a su comprador el disfrute de efectos taumatúrgicos — «quien la traxere consigo, no morirá sin confesion» por ejemplo- . Índice ultimo..., p. 199.

${ }^{44}$ Con todo relativamente invisibles porque, aun sin pruebas documentales, su existencia se suele presuponer bajo el ascendiente de las investigaciones francesas. Lo vemos con Ofelia REY [ «El comercio de libros en la Galicia del Antiguo Régimen», Obradoiro de historia moderna, 17 (2008), p. 285] cuando refiere que «La ausencia de noticias sobre "colporteurs" o buhoneros no impide pensar que hubiera un mercado de ese tipo, más o menos legal —algo común a toda Europa—.
}

Titivillus, ISSN 2387-0915, ISSN-e 2603-9966, 3 (2017), pp. 91-115 
impresores y libreros castellanos. Sin su concurso no llegamos a entender las abultadas cifras de materiales impresos que hallamos en algunos negocios editoriales ni tampoco la forma en que se producía el acceso a la lectura en el ámbito rural y pequeños y medianos núcleos urbanos. ${ }^{45}$ Con esta primera aproximación hemos intentando dar voz a estos personajes aún a costa de cierta debilidad metodológica (principalmente no haber abordado la revisión de mucha más documentación de forma exhaustiva).

A través de tres casos hemos reconstruido, con distinto detalle, siete perfiles de vendedores ambulantes, todos ellos hombres. Entre ellos no encontramos a un solo invidente, señal de que hay que empezar a abandonar la casi automática identificación del vendedor ambulante con el ciego, si bien su control de los mercados urbanos más importantes y su cercanía a los productores nos recuerdan que tampoco hay que restarles importancia. Socialmente son gentes de procedencia humilde y que no han contado con una capacitación previa en el comercio libresco, algunos ni siquiera saben escribir. Tampoco, frente a lo observado en otros países vecinos, ${ }^{46}$ no advertimos la especialización por parte de individuos o familias de una región concreta en este ramo del comercio. La falta de familia (o de compañeros en el camino), la soltería o una vecindad inestable parecen ser también notas habituales entre este colectivo. La edad, por otra parte, es interesante. Aun cuando encontramos dos vendedores relativamente jóvenes (Liñán, con 30, y Carvallo, con 27 años), no olvidemos recientemente incorporados a esta actividad, resulta más habitual encontrar hombres con edades avanzadas (citar el caso andaluz o el tendero de Haro).

La mayoría parece haber llegado al comercio ambulante de impresos como refugio frente a la pobreza y la falta de oportunidades, bien por ser extranjeros (como Carvallo o Latur), bien por estar incapacitados debido a una enfermedad o a la vejez (como Liñán o el primer vendedor onubense). ${ }^{47}$

\footnotetext{
${ }^{45}$ Sin estas redes de venta no podemos explicar la valoración que un coetáneo hizo de un tipógrafo castellano activo en el segundo tercio del Setecientos: «se hizo famoso y conocido en los rincones más apartados del Reyno por el torrente de coplas y romances que le inundó». Citado por José María PALOMARES, Imprenta e impresores de Valladolid en el siglo XVIII, Valladolid, Universidad, 1974, p. 33. Es de justicia, por otra parte, reconocer el papel jugado en la comercialización de impresos por las ferias celebradas en poblaciones pequeñas-medianas y cuya importancia se empieza a desvelar. Como ocurría en el caso navarro no era muy extraño encontrar en ellas a un librero o impresor, o uno de sus empleados, llegados ex-profeso desde Pamplona para vender una selección de sus fondos. ITÚRBIDE, Libros..., anexo CD, pp. 98, 125, 139, 175, y 374.

46 Frédéric BARBIER, Historia del libro, Madrid, Alianza Editorial, 2015, pp. 220-222; SALMAN, «Pedlars...», pp. 120-121, 179, 186-187, 239-243.

47 El perfil socioeconómico de los vendedores estudiados valida las declaraciones sobre este colectivo vertidas en 1748 por el impresor Antonio Sanz (GOMIS, Menudencias..., p. 144): «muchos pobres, que por su hedad no pueden trabajar, y otros, que aviendo servido a Su Magestad se hallan deformados por inválidos, y se aplican a venderlos para ganar su preciso alimento».
} 
Aunque encontramos una mayoritaria especialización en la venta ambulante de impresos, sin otra ocupación que la venta complementaria de mercería o quincallería, también hay casos, como el tendero de Haro, en el que la venta de impresos se reduce a un título de demanda estacional.

En cuanto a sus prácticas comerciales asistimos, aun dentro de un general vagamundeo, ante circuitos de venta con cierta estabilidad, de alcance regional y que pivotan en torno a uno o varios centros de producción editorial. Este tipo de desplazamientos, por lo común, a pie y con el hato o zurrón con sus impresos a cuestas, parece haber sido la norma, lo que deja algunos producidos a escala nacional como casos excepcionales o más propios de épocas pasadas. ${ }^{48} \mathrm{La}$ posesión de una caballería con la que transportar sus mercancías parece haber sido minoritaria entre estos vendedores si bien su posesión implicaba mayor capacidad financiera al tiempo que permitía jugar otro rol en el mercado de impresos (como transportar mayor cantidad y variedad de impresos o el de abastecer al por mayor a otros buhoneros menos afortunados). Se confirma también la participación, consciente o no, de estos vendedores en la distribución de productos impresos ilegales o perseguidos.

El capital acumulado en este comercio no iba a hacer rico a ninguno de ellos pues los beneficios se consumían en sus necesidades básicas y en renovar la mercancías. Su relación con los impresores parece variar de unos centros a otros: frente a Madrid o Sevilla, donde predominaba una relación impersonal entre vendedor y productor, resultado del gran número de intermediarios disponibles, encontramos en una pequeña ciudad de provincias como Logroño una relación de confianza, tanto personal como económica. Aun así, y en todos los casos, vemos cómo los buhoneros acuden a surtirse de forma preferente a un único taller frente a otros en la misma población.

Las mercancías ofertadas por estos vendedores no ofrecen sorpresas. Una y otra vez aparecen, en sus talegos, impresos de pequeña extensión, por lo general, sin encuadernar, y de una misma temática ajustada a una amplia demanda no especializada: literatura devocional —obritas religiosas, grabados, rezos de santos, novenas-, de entretenimiento - romances, coplas-, educativas — cartillas - o de cierta actualidad — relaciones de sucesos, calendarios- Llama la atención, no obstante, la ausencia de referencias a la compra-venta de textos teatrales (comedias y entremeses), un producto editorial muy habitual en los surtidos de las imprentas españolas desde mediados del XVII.49 Indicar, además, que los vendedores, dentro de su especialización, parecen concentrar el grueso de su inversión en un único producto editorial — sean coplas, sean estampas o sean romances- y que acompañarán, en menores cantidades, por otros impresos de diferente

${ }^{48}$ Como los recogidos en Botrel, Libros..., pp. 139-140 o ITÚRBIDE, Los libros..., anexo CD, p. 5.

${ }^{49}$ François LOPEZ, «De la comedia al entremés: Apuntes sobre la edición de obras teatrales en el siglo XVIII» en Coloquio Internacional sobre el Teatro Español del Siglo XVIII, Bolonia, Piovan, 1988, pp. 239-254.

Titivillus, ISSN 2387-0915, ISSN-e 2603-9966, 3 (2017), pp. 91-115 
contenido pero de similares características materiales. Las cifras entresacadas de esta documentación nos orientan asimismo sobre el volumen de capital movilizado por estos buhoneros: nos encontramos ante inversiones mínimas de diez reales a treinta reales — las más comunes- y que se producen de forma escalonada, frente a una máxima, de casi 340 reales. ${ }^{50}$ Las cantidades compradas por título oscilan en función de los precios pero lo más corriente parece haber sido una cantidad inferior a media resma — diez manos- frente a casos más excepcionales, como las seis resmas de estampas compradas por el francés Latur.

Reuniendo todos estos datos advertimos que, de acuerdo a la clasificación de Jeroen Salman, ${ }^{51}$ nuestros protagonistas se inscriben dentro de los niveles más modestos del comercio del libro ambulante. Son los buhoneros que comercian únicamente con productos impresos («Pedlars with printed wares exclusivily») los mejor representados en nuestro estudio: piénsese en la actividad desempeñada por Pedro Liñán o por los vendedores de Huelva. Otra categoría vendría significada por aquellos buhoneros que combinaban la venta de impresos con otros productos («Pedlars of books and other goods») y que en nuestro estudio hemos identificado con Juan Carvallo, al ofertar este, además de impresos, bisutería y negociar con piezas de metal usadas. En este último grupo también podría entrar, si bien con reservas (por vender al por mayor y sólo ofertar un sólo título de demanda estacional), el anónimo proveedor del quinquillero de Haro, el cual, además de ofertar productos textiles, vendía pronósticos. Finalmente Gregorio Fernández, aparecido en el primer caso, se incluiría dentro de esos vendedores («Occasional pedlars») que desempeñando otras profesiones — tendero en este caso- redondeaban sus ingresos con la venta de un impreso concreto (generalmente almanaques) durante una época específica del año.

Gracias al estudio de la identidad y trayectoria de algunos vendedores ambulantes de impresos hemos podido conocer mejor esta modalidad comercial y a sus protagonistas. No obstante, son necesarias más investigaciones que enriquezcan y discutan nuestra aproximación al tiempo que nos desvelen la identidad de otros participantes en este comercio y que hoy por hoy apenas conocemos por referencias indirectas. ${ }^{52}$

50 BOTREL, Libros..., p. 123 recoge como gasto mínimo entre los ciegos madrileños la cantidad de diez reales, el precio de tres manos, y la considera «una inversión razonable en relación con sus posibilidades financieras».

51 SALMAN, «Pedlars...», pp. 118-163.

52 Pensamos en los libreros ambulantes que vendían por caminos y poblaciones libros encuadernados transportados en caballerías aparte de menudencias, y que quizás también encuadernaban. Por ejemplo sabemos que «hubo á mediados de este siglo [XVIII] algunos libreros que se dedicaron á recorrer diferentes provincias del reino, y también se alargaron á Portugal y Mallorca. Estos llevaban una porcion de libros de surtido de sermones, teología moral y escolástica, novelas y otros según el gusto del tiempo». Francisco MÉNDEZ, Tipografía española o Historia de la introducción, propagación y progresos del arte de la imprenta en España, Madrid, Imprenta de las Escuelas Pías, 1861, p. XII. 